\title{
Migration, Remittances, and Household Welfare: Evidence from Pakistan
}

\author{
Masood Sarwar Awan*, Mohsin Javed ${ }^{* *}$, Muhammad Waqas ${ }^{* * *}$
}

\begin{abstract}
This study examines the costs and household-level benefits of overseas migration in Toba Tek Singh, Pakistan. A household survey was conducted to assess the transaction costs associated with the transfer of remittances and the sources used to finance overseas migration. We also carry out a propensity-score matching exercise, which reveals that overseas migration has substantial benefits as measured by migrants' consumption levels, their expenditures on health, education, and vehicles, and the level of household savings. Policy options to facilitate migration and the transfer of remittances include (i) establishing technical training institutions to help workers upgrade their skills, (ii) information campaigns on the migration process and opportunities available, (iii) setting up institutions to provide loans for potential migrants, (iv) reducing money transfer costs through formal channels, and (v) building awareness of the Pakistan Remittance Initiative.
\end{abstract}

Keywords: International migration, remittances, Pakistan.

JEL classification: I30, F22, F24.

\section{Introduction}

The role of international migration and remittances in poverty reduction and economic growth is a key issue for most labor-sending countries. Remittances are often an important source of income and help boost growth, particularly in developing countries (Alfieri \& Havinga, 2006).

The United Nations News Centre (2013) indicates that 232 million people in the world live outside their country of birth compared with 175 million in 2000 and 154 million in 1990. The World Bank (2015) reports that international migrants numbered about 247 million in 2013; this is projected to increase by another 3 million in 2015. The remittances received by

\footnotetext{
* Associate professor, Department of Economics, University of Sargodha, Pakistan.

** MPhil student, Department of Economics, University of Sargodha, Pakistan.

*** PhD student, Department of Economics, University of Sargodha, Pakistan.
} 
developing countries are three times the size of official development assistance. World Bank estimates show that, globally, remittances totaled US\$ 583 billion in 2014, of which US\$ 436 billion flowed to developing countries. In 2013, worldwide remittances stood at about US\$ 542 billion, of which developing countries accounted for US\$ 414 billion. The top four recipient countries included India (US\$ 70 billion), China (US\$ 60 billion), the Philippines (US\$ 25 billion), and Mexico (US\$ 22 billion). By 2016, worldwide remittances are projected to reach US\$ 700 billion, with developing countries receiving about US $\$ 540$ billion.

In 2013, Pakistan ranked seventh among the top ten countries receiving migrant remittances in the developing world (US\$ 14.6 billion). So, Pakistani expatriates play a vital role in the country's economic development, boosting its foreign exchange earnings.

The important questions with respect to migration are (i) to what extent this potential can be realized and (ii) whom it benefits. Typically, the upfront costs of migrating and securing employment in a foreign country are very high. Having to pay agents' fees, visa fees, airfares and other related costs represent a significant burden, especially for the poor. Even after overseas employment has been secured, many potential difficulties can arise in transferring remittances from the host country to the home country. Certain factors such as lack of access to the formal banking system and the costs associated with it compel many people to use informal channels such as the hundi or hawala system.

Despite the significance of remittances for Pakistan, a limited number of studies have looked at the issues relating to migrant households. This study contributes to the literature by attempting to identify the cost of migration and its impact on household welfare.

\section{Literature Review}

Much of the literature on remittances focuses on the role of migration in development and poverty reduction. Adams and Cuecuecha (2010), for instance, argue that international remittances have a substantial effect on poverty. Similarly, Gupta, Pattillo, and Wagh (2009) conclude that remittances have a direct poverty-mitigating effect and a positive impact on financial development. Lokshin, Bontch-Osmolovski, and Glinskaya (2010) find that international remittances and increased migration had reduced poverty in Nepal by as much as 20 percent. 
Acosta, Fajnzylber, and Lopez (2007) show that remittances lower poverty levels, albeit to a moderate degree. Koc and Onan (2004) analyze the use of remittances as a poverty reduction strategy and find that it yields positive results. In a study of 33 African countries, Anyanwu and Erhijakpor (2010) find that international remittances had reduced the level, depth, and severity of poverty.

Most studies show that remittances have a positive impact on household welfare. Maphosa (2007) finds that remittances improve living standards, attitudes to education, and access to health facilities, especially in times of financial difficulty. Similarly, Sharma and Zaman (2009) report that international migration carries substantial benefits for migrant households relative to nonmigrant households. They also analyze the cost of migration and the different channels used to transfer remittances.

Sharma (2013) assesses household wellbeing in the western province of Sri Lanka taking into account international contract-based migration. He reports that different types of expenditure are significantly higher among migrant households, including food, nonfood, and health expenditures. Similarly, Jones and Kittisuksathit (2003) observe that returned international migrants enjoy a far higher quality of life than nonmigrant households. Nguyen (2008) supports this finding and shows how international migration improves welfare.

Some studies, however, report that international migration can also have adverse consequences. Halpern-Manners (2011), for example, finds that migration is negatively related to educational outcomes and economic activity among Mexican youth and adults. Milligan and Bohara (2007) conclude that migration has a positive impact on child welfare, but argue that the increase in remittances should not come at the cost of other sources of income, which might otherwise affect child welfare negatively.

The literature on the impacts of migration in Pakistan is limited. Mansuri (2006) and Arif and Chaudhry (2015) notes that international migration has a significant positive effect on school attainment and child labor in rural Pakistan. They also find that it has a positive impact on human capital accumulation with greater migration gains for girls, thus reducing gender inequality in access to education to a substantial degree.

Studying the use of remittance inflows, Airola (2007) observes that, although recipient households tend to engage in conspicuous-rather than productive-consumption, remittance income improves their overall living 
standards and helps boost the economy. Crush and Frayne (2007) agree, pointing to the positive role of migration in economic development.

Given that simple comparisons give biased results, McKenzie, Gibson, and Stillman (2006) suggest choosing an appropriate instrumental variable. Other options include the difference-in-difference approach and propensity-score matching (PSM) method. Heinrich, Maffioli, and Vázquez (2010) and D'Agostino (1998) also point to the increasing use of PSM for policy evaluation purposes, where there is less control over the treatment group, such as in observational studies.

Clearly, in most cases, international migration reduces poverty, improves household wellbeing, reduces unemployment, and has a positive impact on investment as migrants have far higher saving levels than nonmigrants. Although international migration is seen to affect consumption, the purchase of durables, health, and education, its impact on the latter two is mixed. Overall, however, international migration has a positive impact at the household as well as country level, especially in the context of developing countries.

\section{Data and Sampling}

A questionnaire was designed and administered among a sample of 250 households in Toba Tek Singh district, Punjab, to obtain data on their demographic characteristics, the migration process, and the volume of remittances received and sent. Additionally, qualitative discussions were held with respondents to record their perception of migration, the receipt of remittances, its associated benefits, and any other related issues.

In the initial phase of the survey, key informant interviews were conducted with a number of travel agents and private labor exporting agencies in Toba Tek Singh to identify areas where migration was most prevalent. This exercise yielded a list of 25 such villages, of which 10 villages ${ }^{1}$ were selected at random for the final survey. Given that migrant households represented only a small fraction of the total number of households, the former were oversampled to ensure they were adequately represented in the household survey. Thus, half are migrant households and the other half, nonmigrant households.

\footnotetext{
${ }^{1}$ Our key informants identified 25 such villages (chaks), of which 10 were selected at random: 324 JB, 297 GB, 517 GB, 330 GB, 336 GB, 342 GB, 331 GB, 341 GB, 332 GB, and 349 GB.
} 
In each selected village, 25 households were selected randomly, alternating between a choice of 13 migrant and 12 nonmigrant households in one village and 12 migrant and 13 nonmigrant households in the next to maintain the correct balance. As far as possible, the survey team tried to ensure they interviewed the household head; if this was not possible, then any adult familiar with the household's affairs was invited to respond instead. This is important because, in migrant households, the migrating member may be the head of the household.

\section{Methodology}

Given the binary dependent variable, we use a logit model to assess the different factors affecting migration, thus transforming probabilities into log odds. More formally, let $\mathrm{Y}$ be the binary response variable with a value of 1 if the household has a migrant member and 0 otherwise. $\mathrm{P}$ represents the probability of $\mathrm{Y}$ as 1 :

$\mathrm{P}=\operatorname{Prob}(\mathrm{Y}=1)$

Let $X_{1}, X_{2}, \ldots, X_{11}$ represent the different predictor variables.

The logistic regression takes the following form with parameter values estimated using the maximum likelihood method:

$$
\operatorname{Logit}(p)=\log \left(\frac{P}{1-P}\right)=\beta_{0}+\beta_{1} X_{1}+\beta_{2} X_{2}+\cdots+\beta_{11} X_{11}
$$

In terms of probabilities, equation (1) above translates into

$$
P=\frac{\exp \left(\beta_{0}+\beta_{1} X_{1}+\beta_{2} X_{2}+\cdots+\beta_{11} X_{11}\right)}{\left(1+\exp \left(\beta_{0}+\beta_{1} X_{1}+\beta_{2} X_{2}+\cdots+\beta_{11} X_{11}\right)\right)}
$$

As exactly half the sample comprises migrant households and the other half nonmigrant households, the analysis may be biased in the traditional sense due to the lack of randomization (randomization is important in that two groups being treated differently should be comparable). In an observational study, the researcher does not randomly allocate treatments that are beyond the control of the investigator, which can result in inconsistent and biased estimates.

The estimation method used in this study to assess household-level impacts tackles the problem of potential endogeneity and other data limitations, given that migrants and nonmigrants are not identical. Households that provide members the chance to migrate may be better 
socially networked than those that do not. Hence, if the observable data cannot capture relevant household characteristics, the impact estimates may be biased between the two groups.

In this situation, PSM provides the most accurate estimates of the impact of migration when using nonexperimental design methods. Dehejia and Wahba (2002) find that PSM yields consistent and compatible results for the experimental benchmark estimate and examine LaLonde's (1986) evaluations in an observational study.

Let $Y_{i}^{1}$ be the outcome of the $i$ th household if it migrates and $Y_{i}^{0}$ the outcome if it does not migrate. Thus, the impact of migration is

$$
\Delta=Y_{i}^{1}-Y_{i}^{0}
$$

However, either $Y_{i}^{1}$ or $Y_{i}^{0}$ are observable in each case.

Let $\mathrm{D}$ indicate the household's migration status, where $\mathrm{D}$ is 1 if the household has a migrant member and 0 otherwise. The average impact of migration is given by

$$
\begin{aligned}
& E(\Delta \mid X, D=1)=E\left(Y_{1}-Y_{0} \mid X, D=1\right)=E\left(Y_{1} \mid X, D=1\right)- \\
& E\left(Y_{0} \mid X, D=1\right)
\end{aligned}
$$

$X$ is a vector of control variables. This measure is referred to as the average impact of the treatment on the treated.

In the above expression, $E\left(Y_{0} \mid X, D=1\right)$ is not observed. PSM provides a method for estimating this counterfactual (Rosenbaum \& Rubin, 1983).

Let $P(X)=\operatorname{Pr}(D=1 \mid X)$ be the probability of having a migrant family member. PSM is used to construct a comparison group by matching observations with similar values of $P(X)$ of migrants to nonmigrants, with two assumptions:

$$
\begin{aligned}
& \mathrm{E}\left(\mathrm{Y}_{0} \mid \mathrm{X}, \mathrm{D}=1\right)=\mathrm{E}\left(\mathrm{Y}_{0} \mid \mathrm{X}, \mathrm{D}=0\right) \\
& 0<\mathrm{P}(\mathrm{X})<1
\end{aligned}
$$

Equation (4) is known as conditional mean independence and indicates that, after controlling for $X$, the average outcomes of nonmigrants are identical to those of migrants in the counterfactual situation that they 
did not migrate. Equation (5) assures valid matches by assuming that $P(X)$ is well defined for all values of $X$.

Large values of $X$ (the number of characteristics used in matching) can give rise to the "curse of dimensionality" problem, i.e., as the number of characteristics used in matching increases, the chances of finding an exact match are reduced.

Rosenbaum and Rubin (1983) address this problem by suggesting that beneficiaries and nonbeneficiaries be matched solely on the basis of their propensity scores - that is, the estimated probability of being a migrant household, given all observable characteristics. Intuitively, each beneficiary is matched to a nonbeneficiary with the closest probability. Importantly, there is a substantial difference between the outcomes of matched migrants and matched nonmigrants from the observed difference between migrants and nonmigrants.

In order to estimate the propensity scores, the logit model includes both the determinants of migration and the factors that affect consumption outcomes. A probit model could also be used, given that the distribution of both models is almost the same except that different cumulative distribution functions are employed. We then assess the common support of distributions for migrants and nonmigrants, which indicates a substantial overlap between the two-this meets the basic requirement for matching. As mentioned above, we have used different matching techniques to estimate household-level impacts. Average effects are estimated by taking the difference between the treated (matched migrant households) and control (matched nonmigrant households) groups. Bootstrapping has been used for impact estimates with 1,000 replications for each estimate.

\section{Empirical Results and Interpretations}

This section describes the results of the household survey and estimates the household-level impact of migration and remittances.

\subsection{Characteristics of Migrant Households}

The household survey carried out in the ten randomly selected villages shows that international migrants are, on average, 33 years old; 87 percent are male and 13 percent are female (as shown in Table 1). Married individuals are more likely to migrate, accounting for 65 percent of all migrants. On average, migrants have completed nine grades of schooling. 
Table 1: Descriptive statistics for international migrants

\begin{tabular}{llc}
\hline Variable & & Value \\
\hline Age & Mean (years) & 33.09 \\
Education level & Mean (years) & 9.06 \\
\hline Sex & Percent & \\
$\quad$ Male & & 86.90 \\
$\quad$ Female & & 13.10 \\
Marital status & Percent & \\
$\quad$ Married & & 64.60 \\
Unmarried & & 34.80 \\
\hline
\end{tabular}

Source: Authors' household survey.

Table 2 shows that Saudi Arabia is the most popular destination for overseas migration (accounting for 38 percent of migrants), followed by the UK (30 percent), and the UAE (16 percent). the table also shows that migration to other countries such as the US, Kuwait, and Bahrain is not as significant.

Table 2: Most common migrant destinations

\begin{tabular}{lc}
\hline Country & Percent \\
\hline UK & 29.6 \\
US & 1.6 \\
Saudi Arabia & 38.4 \\
Kuwait & 0.8 \\
Bahrain & 1.6 \\
UAE & 16.0 \\
Others & 12.0 \\
\hline
\end{tabular}

Source: Authors' household survey.

\subsection{Costs Associated With Overseas Migration}

Table 3 shows that in most cases (61 percent), friends and relatives in the destination country helped potential migrants relocate, while about 30 percent of all migrants relied on an agent to facilitate the process (Table 3). 
Table 3: Primary agent facilitating migration

\begin{tabular}{lc}
\hline Primary agent facilitating migration & Percent \\
\hline Agent-based & 29.6 \\
Friends and relatives in the destination country & 60.8 \\
Directly recruited by employer & 9.6 \\
Total & 100.0 \\
\hline
\end{tabular}

Source: Authors' household survey.

The total cost incurred in the process includes agents' fees, the cost of a passport, visa fees, the cost of air travel, and other relevant permits. The mean value of the total upfront fee is PRs 197,492 while the median value is PRs 165,000, indicating that some migrants have to pay more (which is likely related to differences in airfare and visa and work permit fees).

As Table 4 shows, there is also a time-cost involved in preparing and finalizing migration-related documents and making the necessary travel arrangements. The average total time-cost is about five months. The necessary time-cost is 20 days (the number of days spent outside the home to complete the paperwork needed).

Table 4: Average time-cost incurred by international migration

\begin{tabular}{lcc}
\hline Value & Total time-cost (months) & Necessary time-cost (days) \\
\hline Mean & 4.85 & 20.21 \\
Median & 4.00 & 18.00 \\
\hline
\end{tabular}

Source: Authors' household survey.

Table 5 shows that about 45 percent of the migrant households reported having used grants from family members to finance their migration. Just under 22 percent had relied on their own cash resources and the same proportion said they had borrowed from friends and relatives (Table 5). Other sources of financing, such as commercial lenders and the sale of land or other assets, are not as significant. 
Table 5: Sources of financing for overseas migrants

\begin{tabular}{lc}
\hline Source of financing & Percent \\
\hline Own cash resources & 21.6 \\
Grant from family members & 44.8 \\
Borrowed from friends and relatives & 21.6 \\
Borrowed from commercial lender & 0.8 \\
Money from mortgaging land & 3.2 \\
Sold land or other assets & 6.4 \\
Others & 1.6 \\
Total & 100.0 \\
\hline
\end{tabular}

Source: Authors' household survey.

\subsection{Remittance Receipt and Processing}

For the whole sample, table shows that the mean annual remittance per migrant is PRs 473,608 while the median amount is much smaller (PRs $370,000)$. This is likely because some migrants are able to remit larger amounts than others (Table 6).

Table 6: Annual receipt of remittances

\begin{tabular}{lc}
\hline Annual receipt of remittances & Value \\
\hline Average amount received per year (PRs) & \\
Mean & $473,608.00$ \\
Median & $370,000.00$ \\
Frequency per year & \\
Mean & 10.06 \\
Median & 12.00 \\
\hline
\end{tabular}

Source: Authors' household survey.

On average, remittances are received ten times a year, implying that almost all households receive remittances roughly every month (shown in Table 6). As Table 7 shows, Saudi Arabia accounts for the largest percentage of remittances at 37 percent, followed by the UK (31) percent, and the UAE (16 percent). This reflects the data in Table 2 on the most common destination countries for migrants. 
Table 7: Percentage of remittances received from each country per year

\begin{tabular}{lc}
\hline Country & Percent \\
\hline UK & 31.2 \\
US & 1.6 \\
Saudi Arabia & 36.8 \\
Kuwait & 0.8 \\
Bahrain & 1.6 \\
UAE & 16.0 \\
Others & 12.0 \\
Total & 100.0 \\
\hline
\end{tabular}

Source: Authors' household survey.

Almost 40 percent of recipient households use their own bank accounts for remittance transfer and 32 percent rely on money transfer companies (as shown in Table 8). The role of the hundi/hawala system remains significant: almost 21 percent of households report using this medium to transfer remittances.

Table 8: Different modes of receipt

\begin{tabular}{lc}
\hline Mode of receipt & Percent \\
\hline Personal delivery by friends or relatives & 5.6 \\
Money transfer company & 32.0 \\
Direct transfer to own bank account & 39.2 \\
Transfer to a third-party bank account & 1.6 \\
Check or bank draft & 0.8 \\
Hundi/hawala & 20.8 \\
\hline
\end{tabular}

Source: Authors' household survey.

Finally, when asked what attribute they considered most important with respect to remittance modes, 78 percent said they valued reliability and thus used their own bank accounts to transfer remittances. About 50 percent of recipient households reported using the hundi/hawala system because it was cheaper than formal channels ( as shown in Table 9). 
Table 9: Reasons for choosing a particular mode of transfer

\begin{tabular}{|c|c|c|c|c|c|}
\hline \multirow[t]{2}{*}{ Mode of transfer } & \multicolumn{5}{|c|}{ Characteristic valued most (percent) } \\
\hline & Speed & Reliability & Proximity & Low cost & Other \\
\hline $\begin{array}{l}\text { Personal delivery by } \\
\text { friends and relatives }\end{array}$ & 0 & 57 & 14 & 14 & 14 \\
\hline Money transfer company & 71 & 21 & 2 & 5 & 0 \\
\hline $\begin{array}{l}\text { Direct transfer to own } \\
\text { bank account }\end{array}$ & 10 & 78 & 10 & 2 & 0 \\
\hline $\begin{array}{l}\text { Transfer to a third-party } \\
\text { bank account }\end{array}$ & 100 & 0 & 0 & 0 & 0 \\
\hline Check or bank draft & 100 & 0 & 0 & 0 & 0 \\
\hline
\end{tabular}

Source: Authors' household survey.

\subsection{Household-Level Impacts of Migration and Remittances}

As mentioned above, the logit model includes the determinants of migration as well as the factors that affect consumption outcomes. Figure A1 in the Appendix illustrates the substantial overlap between the characteristics of migrants and nonmigrants (common support), which allows us to use the PSM technique. The PSM scores are calculated based on the determinants of migration.

The variables that are statistically significant include: agricultural land before migration, the business of the household head before migration, the number of adult females, adult females with primary schooling, and the presence of friends and relatives in the destination country (see Table A1 in the Appendix). This is line with the literature.

\subsubsection{Local Linear Matching}

Local linear matching (LLM) is a nonparametric matching estimator similar to kernel matching, but with the difference that LLM includes - in addition to the intercept-a linear term in the propensity score of a treated individual. This is an advantage when comparison group values are distributed asymmetrically or when there are gaps in the propensity score distribution. LLM uses the weighted average of all individuals in the control group to construct a counterfactual outcome. It assigns a higher weight to observations with closer propensity scores and a lower weight to those farther apart. Figure A2 in the Appendix illustrates the density of the untreated (control) observations, treated observations, and off-support observations. This exercise yields the following results. 
1. The difference between monthly per capita total expenditures, monthly per capita food expenditures, and monthly per capita nonfood expenditures between matched migrant households and matched nonmigrant households is statistically significant. All cases indicate statistically significant expenditures for migrant households.

2. Analyzing other components, such as monthly per capita expenditures on clothing, health, and education, reveals that migrant households spend significantly more than nonmigrants. We find this difference to be statistically significant, although the literature yields mixed results.

3. As expected, migrant households have higher liquidity and are better able to finance expenditures, particularly on vehicles, appliances, and kitchen items. Again, in all cases, migrant households spend significantly more on such items than nonmigrants.

4. A priori, we would expect migrant households to save a significant part of their remittances. This is borne out by the results: there is a significant difference in annual cash savings between migrant and nonmigrant households, with the former saving almost nine times as much as the latter.

5. The volume of outstanding loans for migrant households is not significantly higher. Although they face high upfront costs relating to migration, they are likely to return these loans on a priority basis.

6. Migrant households spend more on the purchase of agricultural land and the difference between the two groups is significant.

Overall, we find that migration and remittances have a positive and significant impact on food and nonfood expenditures, clothing expenditures, health expenditures, education expenditures, the level of cash savings, and changes in agricultural land. The difference between the two groups with respect to outstanding loans is not found to be significant (see Table A2 in the Appendix).

\subsubsection{Bootstrapped Standard Errors for Impact Estimates}

Bootstrapping is a technique through which accuracy measures are assigned to sample estimates, thus allowing one to estimate the sampling distribution of almost any statistic. It can be used to test hypotheses when the parametric assumptions are in doubt or the formulae too complicated to compute standard errors. 
One problem this study faces is that the estimated variance of the treatment effect should also include the variance due to the estimation of the propensity score, the imputation of the common support, and the order in which treated individuals are matched. In this way, the variance goes beyond the normal sampling variation.

This problem is tackled using bootstrapping. Table A3 in the Appendix reports the bootstrapped standard errors and t-statistic values for different matching techniques. The results show that all estimations are compatible and match our findings well.

\subsection{Qualitative Analysis}

Most migrants surveyed had been unemployed workers in their home country with few technical skills and, as a result, low wages. We also found that people were not aware of a wider range of job opportunities available abroad.

\subsection{Balancing Tests}

The study employs the following tests:

- Standardized test for percentage bias

- Test for equality of means

If the conditional independence assumptions hold and exposure to treatment is random, then the matched migrant and matched nonmigrant households should be, on average, identical. Standardized bias is the difference between the sample means of the treated and nontreated (full or matched) subsamples as a percentage of the square root of the average of the sample variances in the treated and nontreated groups. The t-statistic value for equality of means should not be significant. All the variables used in this study pass the balancing tests (see Table A4 in the Appendix).

\section{Conclusion and Policy Implications}

The purpose of this study was to analyze the different costs facing the poorest migrant households and to investigate the effect of remittances on household welfare. Overall, our results show that migration has a significant and positive impact on all the outcome variables. International migration appears to have improved the wellbeing of the sample migrant households and, in future, its impact is expected to be even stronger. 
The results also indicate that the upfront fee required for overseas migration is about PRs 200,000, which is considerably high for a poor household, while the average size of remittances received per year is about PRs 475,000. The largest inflows are from Saudi Arabia. The hundi/hawala system still plays an important role, accounting for 21 percent of the total inflow of remittances, and is associated with a lower transfer cost.

International migration clearly improves household wellbeing: we have observed statistically significant differences between migrant and nonmigrant households with respect to the mean level of per capita total expenditure; per capita expenditure on food, nonfood, health, and education; annual expenditure on appliances and vehicles; the level of savings; and the change in agricultural land. Although migrant households tend to invest more in real estate than in purchasing agricultural land, the change in agricultural land remains significant.

Given the positive and significant impact of international migration on household welfare, the government should formulate a well-defined migration policy and sign bilateral agreements with other countries to enhance migration as a tool to reduce unemployment and poverty.

Migrant earnings-based on the annual average remittances received-are still low, given the low level of skills and technical expertise. Upgrading migrants' skills would improve their wage levels and increase remittance inflows. This requires establishing technical training institutions to allow migrants to eventually avail a wider set of job opportunities abroad. Additionally, the lack of awareness among prospective migrants of migration opportunities and reported cases of exploitation could be addressed through information campaigns and services. The establishment of institutions that offer easy terms (especially in less developed areas) on loans for migration would reduce the financial burden of migrating.

Having identified the important role of informal transfer channels, which are cheaper and easier to access, we recommend improving access to channels such as the Pakistan Remittance Initiative, which allows people living abroad to remit funds free of charge and free of taxes. The government should also launch an information campaign to spread awareness of this service and to help migrants understand the losses associated with informal transfer channels. This would encourage more people to use formal channels to transfer remittances. 


\section{References}

Acosta, P., Fajnzylber, P., \& Lopez, J. H. (2007). The impact of remittances on poverty and human capital: Evidence from Latin American household surveys (Policy Research Working Paper No. 4247). Washington, DC: World Bank.

Adams, R. H. (2009). The determinants of international remittances in developing countries. World Development, 37(1), 93-103.

Adams, R. H., \& Cuecuecha, A. (2010). The economic impact of international remittances on poverty and household consumption and investment in Indonesia (Policy Research Working Paper No. 5433). Washington, DC: World Bank.

Airola, J. (2007). The use of remittance income in Mexico. International Migration Review, 41(4), 850-859.

Alfieri, A., \& Havinga, I. (2006). Issue paper: Definition of remittances. New York, NY: United Nations Statistics Division.

Anyanwu, J., \& Erhijakpor, A. E. O. (2010). Do international remittances affect poverty in Africa? African Development Review, 22(1), 51-91.

Arif \& Chaudhry (2015). The effects of external migration on enrolments, accumulated schooling and dropouts in Punjab. Applied Economics, 47(16), 1607-1632.

Crush, J., \& Frayne, B. (2007). The migration and development nexus in Southern Africa introduction. Development Southern Africa, 24(1), 1-23.

D'Agostino, R. B. (1998). Propensity score methods for bias reduction in the comparison of a treatment to a non-randomized control group. Statistics in Medicine, 17, 2265-2281.

Dehejia, R., \& Wahba, S. (2002). Propensity-score matching methods for nonexperimental causal studies. Review of Economics and Statistics, 84(1), 151-161.

Gupta, S., Pattillo, C. A., \& Wagh, S. (2009). Effect of remittances on poverty and financial development in sub-Saharan Africa. World Development, 37(1), 104-115. 
Halpern-Manners, A. (2011). The effect of family member migration on education and work among nonmigrant youth in Mexico. Demography, 48, 73-99.

Heinrich, C., Maffioli, A., \& Vázquez, G. (2010). A primer for applying propensity-score matching (Technical Notes No. IDB-TN-161). Washington, DC: Inter-American Development Bank.

Jones, H., \& Kittisuksathit, S. (2003). International labor migration and quality of life: Findings from rural Thailand. International Journal of Population Geography, 9(6), 517-530.

Koc, I., \& Onan, I. (2004). International migrants' remittances and welfare status of the left-behind families in Turkey. International Migration Review, 38(1), 78-112.

LaLonde, R. (1986). Evaluating the econometric evaluations of training programs with experimental data. American Economic Review, 76, 604-620.

Lokshin, M., Bontch-Osmolovski, M., \& Glinskaya, E. (2010). Work-related migration and poverty reduction in Nepal. Review of Development Economics, 14(2), 323-332.

Mansuri, G. (2006). Migration, school attainment, and child labor: Evidence from rural Pakistan (Policy Research Working Paper No. 3945). Washington, DC: World Bank.

Maphosa, F. (2007). Remittances and development: The impact of migration to South Africa on rural livelihoods in southern Zimbabwe. Development Southern Africa, 24(1), 123-136.

McKenzie, D., Gibson, J., \& Stillman, S. (2006). How important is selection? Experimental vs. non-experimental measures of the income gains from migration (Policy Research Working Paper No. 3906). Washington, DC: World Bank.

Milligan, M., \& Bohara, A. (2007). The effect of remittances on child labor and child education in Nepal. Unpublished manuscript, University of New Mexico, Albuquerque, NM. Retrieved from (https:/ / ejournals.unm.edu/index.php/nsc/article/view/656/752). 
Nguyen, V. C. (2008). Impacts of international and internal remittances on household welfare: Evidence from Viet Nam (MPRA Paper No. 25770). Retrieved from (http://mpra.ub.uni-muenchen.de/25770/1/ MPRA_paper_25770.pdf).

Rosenbaum, P. R., \& Rubin, D. B. (1983). The central role of the propensity score in observational studies for causal effects. Biometrika, 70(1), $41-55$.

Sharma, M. P. (2013). International contract-based migration, remittances, and household wellbeing in the western province of Sri Lanka. International Migration, 51(S1), 216-248.

Sharma, M., \& Zaman, H. (2009). Who migrates overseas and is it worth their while? An assessment of household survey data from Bangladesh (Policy Research Working Paper No. 5018). Washington, DC: World Bank.

United Nations News Centre. (2013, 11 October). Number of international migrants rises above 232 million, UN reports [Webpage]. Retrieved from (http://www.un.org/apps/news/story.asp?NewsID=45819\#.UleA3 IZkNSk).

World Bank. (2015). Prospects: Migration and remittances [Webpage]. Retrieved 2 May 2015, from (http://econ.worldbank.org/ WBSITE/EXTERNAL/EXTDEC/EXTDECPROSPECTS/0, content MDK:21121930 menuPK:3145470 pagePK:64165401 piPK:641650 26 theSitePK:476883,00.html). 


\section{Appendix}

Figure 1: Common support required for PSM

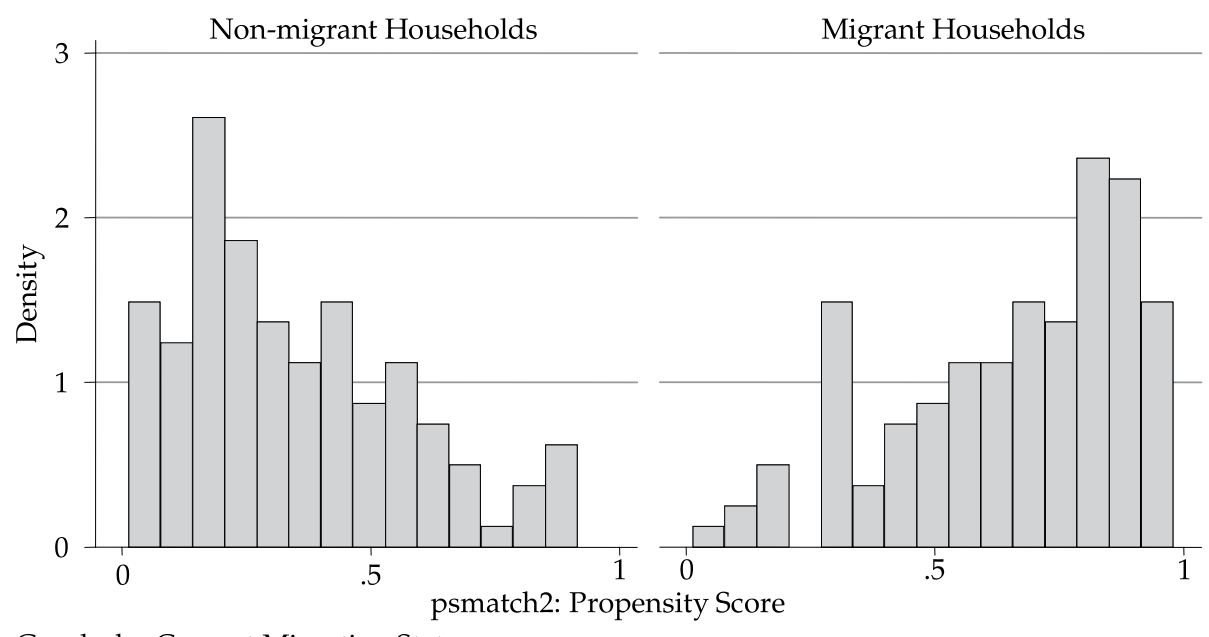

Graphs by Current Migration Status

Figure 2: Visual analysis of treated and untreated (control) observations

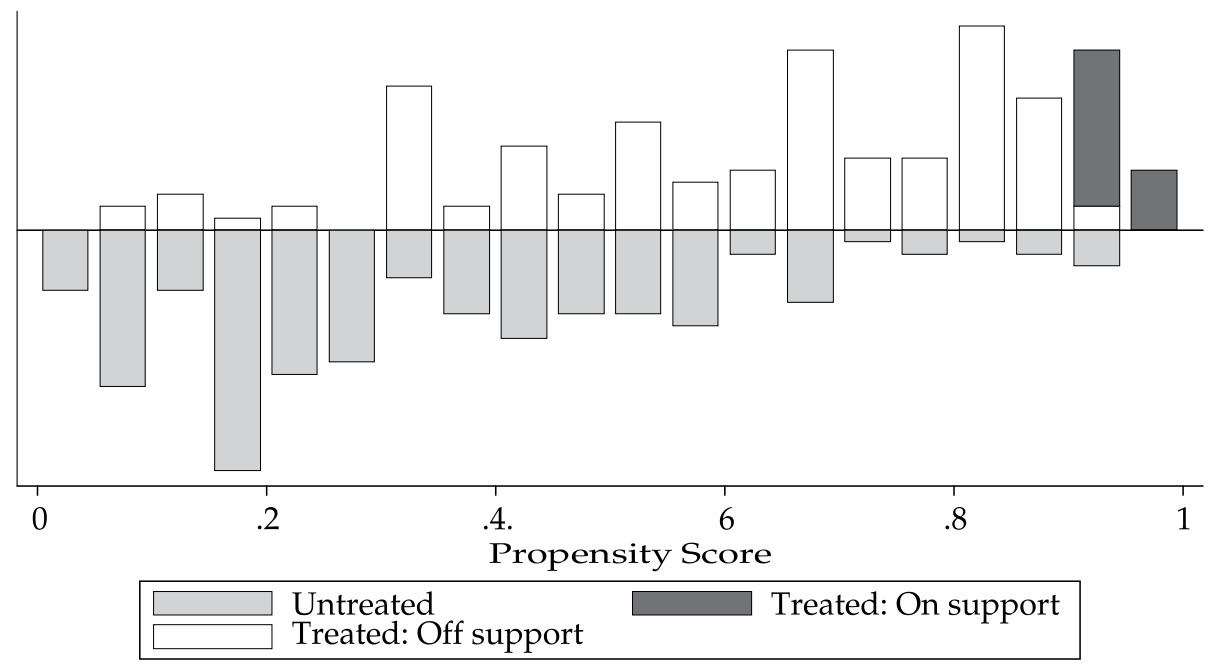


Table A1: Determinants of migration status (logit probability model)

Dependent variable $=$ migration status

\begin{tabular}{lccc}
\hline Variable & Coefficient & Standard error & T-statistic \\
\hline Home area before migration & 0.007313 & 0.030104 & 0.24 \\
Agricultural land before migration & -0.111950 & 0.036849 & $-3.04^{* *}$ \\
$\begin{array}{l}\text { Business of household head before migration } \\
\text { (Nonagricultural = 1, otherwise = ) }\end{array}$ & -1.306060 & 0.361867 & $-3.61^{* *}$ \\
Household head's occupation before migration & & & 1.55 \\
(Wage laborer = 1, otherwise =) & 0.882882 & 0.569082 & 1.16 \\
Number of adult males & & & $-2.06^{* *}$ \\
Number of adult females & 0.506220 & 0.436478 & -0.01 \\
Adult males with primary schooling & -0.675480 & 0.328461 & $1.87^{*}$ \\
Adult females with primary schooling & -0.003490 & 0.425317 & 0.32 \\
Household head's education level & 0.603828 & 0.323550 & -0.48 \\
Spouse's education level & 0.019502 & 0.060380 & $2.23^{* *}$ \\
Maximum education among adults & -0.002520 & 0.005287 & $6.05^{* *}$ \\
Friends and relatives in destination country & 0.168232 & 0.075440 & $-3.61^{* *}$ \\
(Yes =1, no =) & 2.050815 & 0.338733 & \\
_cons & & & \multicolumn{2}{c}{} \\
\hline
\end{tabular}

Note: * and ${ }^{* *}$ denote significance at $10 \%$ and $5 \%$, respectively.

Source: Authors' calculations. 
Table A2: Household-level impacts of migration and remittances (LLM)

\begin{tabular}{|c|c|c|c|c|c|}
\hline Outcome variable & Sample & Treated & Control & Difference & T-statistic \\
\hline \multirow[t]{2}{*}{ Monthly per capita total expenditures } & Unmatched & $6,715.616$ & $2,877.352$ & $3,838.264$ & 10.11 \\
\hline & ATT & $6,703.533$ & $2,856.038$ & $3,847.494$ & \\
\hline \multirow[t]{2}{*}{ Monthly per capita food expenditures } & Unmatched & $3,325.104$ & $1,529.536$ & $1,795.568$ & 8.05 \\
\hline & ATT & $3,321.598$ & $1,514.252$ & $1,807.346$ & \\
\hline \multirow[t]{2}{*}{ Monthly per capita nonfood expenditures } & Unmatched & 910.208 & 396.632 & 513.576 & 7.63 \\
\hline & ATT & 882.215 & 386.1463 & 496.0687 & \\
\hline \multirow[t]{2}{*}{ Monthly per capita clothing expenditures } & Unmatched & 289.048 & 101.344 & 187.704 & 9.66 \\
\hline & ATT & 275.0187 & 104.115 & 170.9037 & \\
\hline \multirow[t]{2}{*}{ Monthly per capita health expenditures } & Unmatched & 740.248 & 373.84 & 366.408 & 6.26 \\
\hline & ATT & 772.7196 & 381.1806 & 391.539 & \\
\hline \multirow[t]{2}{*}{ Monthly per capita education expenditures } & Unmatched & $1,073.488$ & 411.832 & 661.656 & 5.33 \\
\hline & ATT & $1,089.065$ & 398.2518 & 690.8136 & \\
\hline \multirow[t]{2}{*}{ Monthly per capita expenditure on utensils } & Unmatched & 202.72 & 55.6 & 147.12 & 12.07 \\
\hline & ATT & 200.0748 & 59.98856 & 140.0862 & \\
\hline \multirow[t]{2}{*}{ Annual expenditure on appliances } & Unmatched & $6,645.064$ & $1,135.2$ & $5,509.864$ & 11.70 \\
\hline & ATT & $6,529.28$ & $1,394.651$ & $5,134.629$ & \\
\hline \multirow[t]{2}{*}{ Annual expenditure on vehicles } & Unmatched & $20,382.4$ & 2,248 & $18,134.4$ & 5.03 \\
\hline & ATT & $21,199.07$ & $2,503.996$ & $18,695.07$ & \\
\hline \multirow[t]{2}{*}{ Annual cash savings } & Unmatched & $110,026.4$ & $11,783.2$ & $98,243.2$ & 8.50 \\
\hline & ATT & $102,488.8$ & $15,128.25$ & $87,360.53$ & \\
\hline \multirow[t]{2}{*}{ Outstanding loans } & Unmatched & 18,664 & $9,632.56$ & $9,031.44$ & 1.45 \\
\hline & ATT & $20,869.16$ & $8,126.482$ & $12,742.68$ & \\
\hline \multirow[t]{2}{*}{ Change in agricultural land } & Unmatched & 1.9536 & 0.344 & 1.6096 & 3.58 \\
\hline & ATT & 1.71215 & 0.151376 & 1.560773 & \\
\hline
\end{tabular}

Source: Authors' calculations. 
Table A3: Household-level impacts of migration and remittances (bootstrapped standard errors for LLM)

\begin{tabular}{lccc}
\hline Outcome variables & Observed coefficient & Bootstrapped SE & T-stat. \\
\hline Monthly per capita total expenditures & $3,847.494$ & 489.4818 & $7.86^{* *}$ \\
Monthly per capita food expenditures & $1,807.346$ & 277.214 & $6.52^{* *}$ \\
Monthly per capita nonfood expenditures & 496.0687 & 98.25386 & $5.05^{* *}$ \\
Monthly per capita clothing expenditures & 170.9037 & 25.8406 & $6.61^{* *}$ \\
Monthly per capita health expenditures & 391.539 & 95.02494 & $4.12^{* *}$ \\
Monthly per capita education expenditures & 690.8136 & 156.5896 & $4.41^{* *}$ \\
Monthly per capita expenditure on utensils & 140.0862 & 15.90433 & $8.81^{* *}$ \\
Annual expenditure on appliances & $5,134.629$ & 560.191 & $9.17^{* *}$ \\
Annual expenditure on vehicles & $18,695.07$ & $4,117.144$ & $4.54^{* *}$ \\
Annual cash savings & $87,360.53$ & $12,417.43$ & $7.04^{* *}$ \\
Outstanding loans & $12,742.68$ & $8,506.773$ & 1.50 \\
Change in agricultural land & 1.560773 & 0.533083 & $2.93^{* *}$ \\
\hline
\end{tabular}

Note: ${ }^{*}$ and ${ }^{* *}$ denote significance at $10 \%$ and $5 \%$, respectively.

Source: Authors' calculations. 
Table A4: Matching quality for LLM

\begin{tabular}{|c|c|c|c|c|c|c|}
\hline \multirow[b]{2}{*}{ Variable } & & \multicolumn{2}{|c|}{ Mean } & \multirow[b]{2}{*}{ \%bias } & \multirow[b]{2}{*}{$\begin{array}{l}\text { \% reduction } \\
\text { in | bias | }\end{array}$} & \multirow[b]{2}{*}{ T-stat. } \\
\hline & & Treated & Control & & & \\
\hline \multirow[t]{2}{*}{ Home area before migration } & Unmatched & 9.256 & 8.216 & 14.8 & & 1.17 \\
\hline & Matched & 8.1682 & 7.5047 & 9.5 & 36.2 & 0.85 \\
\hline \multirow{2}{*}{ Agricultural land before migration } & Unmatched & 3.6324 & 3.713 & -1.4 & & -0.11 \\
\hline & Matched & 3.7131 & 3.4729 & 4.3 & -198.1 & 0.30 \\
\hline \multirow[t]{2}{*}{ Business of household head before migration } & Unmatched & 0.36 & 0.536 & -35.8 & & $-2.83^{* *}$ \\
\hline & Matched & 0.37383 & 0.42056 & -9.5 & 73.4 & -0.70 \\
\hline \multirow[t]{2}{*}{ Household head's occupation before migration } & Unmatched & 0.096 & 0.128 & -10.1 & & -0.80 \\
\hline & Matched & 0.09346 & 0.16822 & -23.6 & -133.6 & -1.62 \\
\hline \multirow[t]{2}{*}{ Number of adult males } & Unmatched & 2.56 & 1.96 & 46.6 & & $3.68^{* *}$ \\
\hline & Matched & 2.3364 & 2.4299 & -7.3 & 84.4 & -0.53 \\
\hline \multirow[t]{2}{*}{ Number of adult females } & Unmatched & 2.024 & 1.752 & 25.7 & & $2.03^{* *}$ \\
\hline & Matched & 1.8972 & 2.1215 & -21.2 & 17.5 & -1.51 \\
\hline \multirow{2}{*}{ Adult males with primary schooling } & Unmatched & 2.376 & 1.736 & 50.3 & & $3.98^{* *}$ \\
\hline & Matched & 2.1589 & 2.2617 & -8.1 & 83.9 & -0.59 \\
\hline \multirow[t]{2}{*}{ Adult females with primary schooling } & Unmatched & 1.68 & 1.264 & 40.2 & & $3.18^{* *}$ \\
\hline & Matched & 1.5421 & 1.6542 & -10.8 & 73 & -0.81 \\
\hline \multirow[t]{2}{*}{ Household head's education level } & Unmatched & 7.912 & 7.144 & 18.3 & & 1.45 \\
\hline & Matched & 7.972 & 7.5888 & 9.1 & 50.1 & 0.73 \\
\hline \multirow[t]{2}{*}{ Spouse's education level } & Unmatched & 16.888 & 17.168 & -0.9 & & -0.07 \\
\hline & Matched & 18.664 & 12.794 & 19.1 & $-1,996.1$ & 1.47 \\
\hline \multirow[t]{2}{*}{ Maximum education among adults } & Unmatched & 11.568 & 9.96 & 53.8 & & $4.26^{* *}$ \\
\hline & Matched & 11.299 & 10.533 & 25.7 & 52.3 & 2.03 \\
\hline \multirow{2}{*}{ Friends and relatives in destination country } & Unmatched & 0.616 & 0.224 & 86.2 & & $6.81^{* *}$ \\
\hline & Matched & 0.5514 & 0.61682 & -14.4 & 83.3 & -0.97 \\
\hline
\end{tabular}

Note: ${ }^{*}$ and ${ }^{* *}$ denote significance at $10 \%$ and $5 \%$, respectively.

Source: Authors' calculations. 